\title{
TRANSLATING PROPER NAMES IN A LITERARY TEXT: A CASE OF HARRY POTTER NOVEL IN VIETNAM
}

\author{
Trieu Thu Hang* \\ Faculty of English Language Teacher Education, VNU University of Languages and International \\ Studies, Pham Van Dong, Cau Giay, Hanoi, Vietnam
}

Received 22 January 2018

Revised 21 March 2018; Accepted 30 March 2018

\begin{abstract}
Translating literary proper names is regarded as one of the challenging but inspiring issues in the field of Translation Studies. Given this context, the present paper aims to analyze the strategies undertaken by the translator when rendering proper names from the English literary text "Harry Potter and the Philosopher's Stone" (2014) into its Vietnamese translation "Harry Potter và Hòn đá phù thuỷ" (2016). To fulfill the research purpose, a descriptive and comparative analysis was made between the source and target text. The analysis of translation strategies was grounded on the theoretical frame of Davis (2003). The findings reveal that the translator adopted the strategy of preservation for most of the proper names in the chosen literary text. Several recommendations for translating proper names in the literary texts are finally drawn out.
\end{abstract}

Keywords: translating proper names, literary text

\section{Rationale}

Hermans $(1988, p .12)$ accentuates that proper names "occupyan exceptional position withregard to the language system". Accordingly, translating literary proper names is one of the challenging but inspiring issues in the field of Translation Studies. It is sufficiently challenging when it comes to the translation of the phenomenal Harry Potter novel because this literary text embraces a myriad of unique features, including literary meaningful proper names. Given this context, the paper aims to analyze the translation strategies adopted by the translator in rendering the proper names from the English source text "Harry Potter and the Philosopher's Stone" (2014) into the target culture of Vietnam.

\section{Literature review}

\subsection{Literary proper names}

According to the Oxford Dictionary of English (hereafter ODE), a proper name is

\footnotetext{
* Tel.: 84-944811991

Email: trieuthuhang91@gmail.com
}

broadly perceived as a name for an individual person, a place, or an organization having an initial capital letter. In literary texts, proper names merit close attention because of their roles to the characterization, their functions and their effects to the entire text. Therefore, Hermans (1988) generally classifies proper names into conventional and loaded names in which loaded names are commonly employed in literary texts.

More specifically, Fernandes (2006) groups literary proper names into three categories, including semantically loaded names, semiotically loaded names, and phonologically loaded names. Firstly, semantically loaded names display the distinctive qualities of the characters and are common in allegorical literary works. In other words, the name of the character reflects his or her personality, furnishes the readers with obvious clues about the destiny of the character or discloses the way the storyline develops.

Secondly, semiotically loaded names might associate with mythology, social 
class, nationality and gender. As an example, "Minerva" in Harry Potter novel is imbued with a mythological Latin name for Athena who is a cerebral Roman goddess of wisdom. Besides, names carrying semiotic meaning disclose the gender of the character. For example, it is possible for the readers to notice that Harry is a male name, and Ginny is a female name. Names carrying semiotic meaning might suggest social class and nationality. For instance, Sir Nicolas De Mimsy-Porpington is a name of aristocratic class, and "Padma" and "Parvati Patil" are from Indian.

Thirdly, phonologically loaded names are comprised of imitative and phonesthetic names. Regarding the former, imitative names make use of onomatopoeia. For instance, Mrs. Norris is a cat in the Harry Potter saga, and her name imitates the sounds she emits when she is irritated. As for the latter, phonesthetic names are grounded on the employment of sounds or sound clusters, which firmly links with a meaning. For instance, the cluster /gl/ are in glisten, glow, glimmer, glitter, etc., words that are commonly connected with light.

Concerning the literary text "Harry Potter and the Philosopher's Stone" (hereafter HPPS), the findings from previous studies (Inggs, 2003; Wyler, 2003; Nilsen and Nilsen, 2005; Nilsen and Nilsen, 2009; Brondsted and Dollerup, 2010) confirm that the proper names in HPPS demonstrate the multilayered meanings to develop the general theme of the story. The names in HPPS fulfills the manifold functions of provoking connotations, specifying the roles of the characters, providing the portrayal of individual traits, creating the aesthetic appeal of a literary text, entertaining and assisting the readers in absorbing an abundance of names.

Overall, the author agrees that proper names are of significance in literary texts. As a magnetic field attracting other characteristics that constitute the character (Barthes, 1970), proper names serve as an ideal vehicle of characterization. Wellek and Warren (1976, p.219) adopt the similar standpoint that proper names in literary texts serve as "a kind of vivifying, animizing and individuating". Manini (2014) also reaffirms the close bond between the personal attributes and the character names to achieve artistic expression in the narrative fiction.

\subsection{Strategies to translate proper names}

In the present paper, the analysis of translation strategies is grounded on the theoretical frame of Davis (2003). Her model of translation strategies has generally been conducted to deal with culture-specific references in Harry Potter saga in the language pair of French-German and Italian-Chinese. Since proper name is a sub-category of culture-specific references (Klingberg, 1986; Newmark, 1988; Aixela, 1996), the frame of Davis is adopted for the translation strategy analysis of proper names in this paper.

Davis (2003) proposes seven strategies, including preservation, addition, globalization, localization, transformation, creation and omission. Regarding preservation, there are two types of preservation. The first type is keeping the original non-translated in the target culture, which is similar to the strategy of transference offered by Newmark (1988). The second type is literal translation without any attached explanation. As for "Addition", the translator preserves the original item but adds the text with the essential explanation. The additional information could be inserted in the main text or outside the text as a footnote or as a glossary at end of the book. "Globalization" means replacing the cultural item with a more neutral and general term so that it is accessible to the readers from a wider range of cultural backgrounds. Localization is the opposite of Globalization. By adopting localization, the translator "anchors a 
reference firmly" in the target culture rather than providing "culture-free description" (Davis, 2003, p.83). Transformation means adapting the original that goes beyond globalization or localization. Finally, "Creation" touches on the creation of a reference that is different from the source reference. The aforementioned translation strategies are grouped under the overall pattern of source and target text-oriented translation as follows: been translated into more than 73 languages with over 400 million copies sold.

To fulfill the research purpose, a brief overview on HPPS is provided. Rowling creates the narrative of the protagonist Harry Potter, a young wizard studying first year at the Hogwarts School of Wizards. Harry faces the resurrection of the dark wizard Lord Voldemort who killed his parents. The wizard world is separated into two sides representing the utmost good and the utmost evil during an on-going

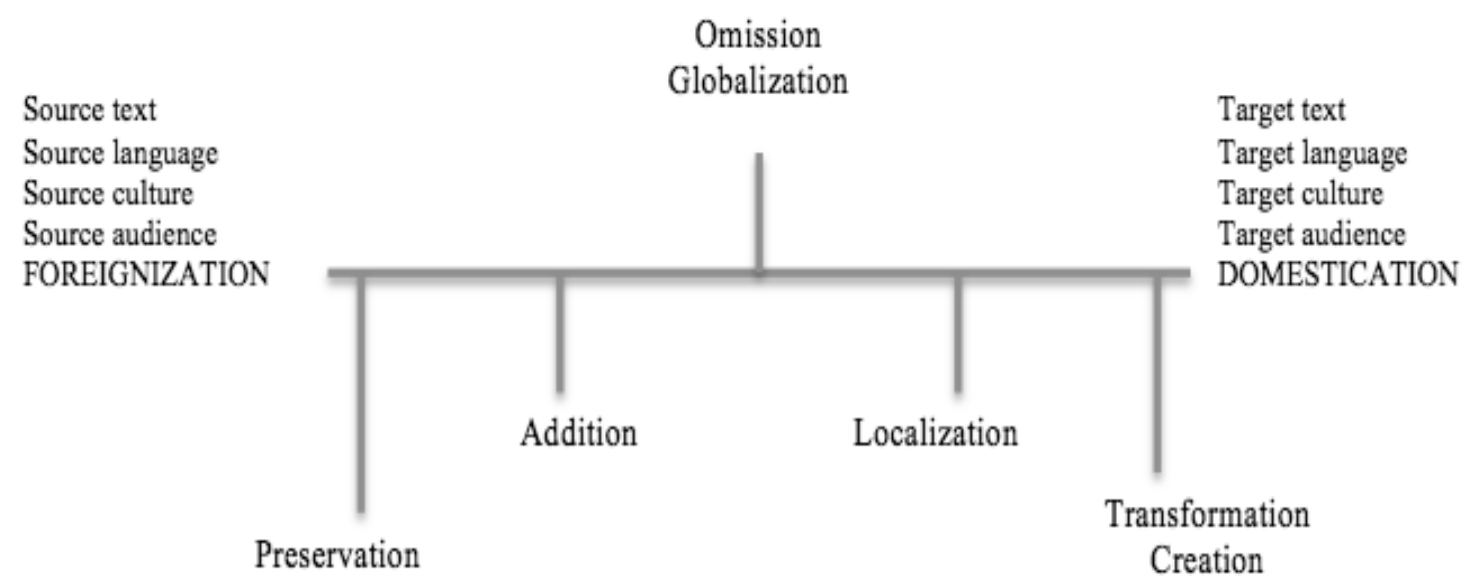

Figure 1. The spectrum of translation strategies of Davis (2003) as cited in Jaleniauskiene \& Cicelite (2009, p. 33)

\section{Methodology}

The present paper is a descriptive and comparative analysis of translation strategies in dealing with literary proper names in "Harry Potter and the Philosopher's Stone" (HPPS). The English literary text chosen is "Harry Potter and the Philosopher's Stone" (2014) by J. K. Rowling, and its comparative Vietnamese translation is "Harry Potter và Hòn đá phù thuỷ” (2016) translated by Lý Lan. Both Harry Potter saga and "Harry Potter and the Philosopher's Stone" (2014) have gained huge popularity and notable literary prizes across the globe since 1997, which clearly merits the research attention. The original has battle. Harry, his best friends, and the headmaster Dumbledore of Hogwarts school represent the good wizards, whereas the evil side gets support from the Lord Voldemort, the Malfoys, and their friends. The narrative covers the subject matters of boarding school life, mysteries, adventures, battle between the good and the evil that are situated in both the real-life British background and the fantasy wizard community.

\section{Findings and discussion}

\subsection{Proper names of students}

The comparative analysis reveals that the strategy of "preservation" was adopted for most of the proper names of students in HPPS. In HPPS, there are conventional 
names of minor characters merely performing the referential function, serving to create the milieu of the Hogwarts' school environment. They are Abbott Hanna, Adrian Pucey, Alicia Spinnet, Angelina Johnson, Bones Susan, Boot Terry, Brocklehurst Mandy, Dean Thomas, Brown Lavender, Mulstrode Millicent, Finch Fletchley, Finnigan Seamus, Marcus Flint, Parkinson, Perks Sally Anne, and Parvati Patil. These conventional names appear once when the Sorting Hat classifies students into four Houses at Hogwarts school. It is stressed that these names merely play the role of creating an overall atmosphere of the boarding school, and the functions of these names are mere identification. Accordingly, the preservation of these names brings the exotic scent and foreignness to the target readers.

More significantly, there are loaded names not only performing the function of identification but also bearing connotations in HPPS. Likewise, the strategy of preservation was adopted for the rendition of these names into the Vietnamese culture. They are the names of the protagonist and other major characters such as "Harry", "Hermione", "Ron", "Draco Malfoy", which stores information about the distinctive traits of the characters. The author believes that the strategy of preservation in these cases possibly makes the target readers difficult to get accessible to the intended implications.

Take the name of the protagonist "Harry" as an example. First, it is a prototypical British name and among the top five most trendy baby names in Britain (Office for National Statistics, 2011). For this reason, the author agrees that the Vietnamese readers are sent abroad to savor the British flavor through the strategy of preservation. Nevertheless, the name "Harry" rings a bell with the British readers of a medieval English form of Henry, a favorite name of English rulers from Henry
I (1087-1121) to Henry VIII (1509-1547). There comes an anonymous poem about the Kings and Queens of England taught at English schools to show that Harry is a common name of English rulers:

Willie, Willie, Harry, Ste, Harry, Dick, John, Harry three; One two three Neds, Richard two, Harrys four five six, ... then who?

Edwards four five, Dick the bad, Harrys (twain), Ned (the lad)... ${ }^{(1)}$

Evidently, the sense of leadership runs deep in the name Harry, supplying the readers with the clues about the destiny of the protagonist. As this name is continuously repeated all over the story, it brings a fragrance reminiscent of the Britishness and evokes the sense of leadership of a great hero. Therefore, the strategy of preservation might challenge the general readers in the target Vietnamese culture in interpreting such positive connotation connected with the name.

As Harry's best friends, the names of "Hermione" and "Ron" should be taken into account. Historically, the name "Hermione" carries mythological connotation. "Hermione" is a derivative feminine inflection of the name Hermes of a Greek god. In an interview ${ }^{(2)}$ with the author of Harry Potter novel, Rowling (1999) also confirms that she borrows her character names from medieval saints. Additionally, Hermione rings a bell with the British readers of the daughter of the King Menelaus of Sparta and Helen of Troy. For the educated Britons, this name alludes to the wife of the King Sicily in the masterpiece "The Winter's Tale" of William Shakespeare (Brondsted and Dollerup, 2010). For the name "Ron" (Ronald), there exists a close bond between the name and the role of this

\footnotetext{
1 Retrieved 25th January from http://www.britannia. com/history/h6.html

${ }^{2}$ Retrieved 22 January 2018 from http://www.accioquote.org/articles/list1999.html
} 
character in the narrative. Ronald ${ }^{(3)}$ is derived from a Scottish name "Rögnvaldr", which alludes to the adviser of a ruler. This name clearly reflects the role of Ron who serves as an adviser of the protagonist. Meanwhile the strategy of preservation effectively escorts the Vietnamese readers to the European foreign culture, it possibly makes them demanding to decode the purposeful meanings embedded in these names.

The negative connotation is vividly evoked from the name "Draco Malfoy", one of Harry's enemies at Hogwarts wizard school. Likewise, this name was preserved in the target culture. "Draco" remains deeply rooted in Latin for dragon that reminds the readers of "dracula or dragons" (Oittinen, 2008, p. 125). In Western culture, dragon is associated with the evil (Compagnone and Danesi, 2013; Nguyễn Văn Trào, 2014) because it stems from the dragon image of Satan in the Bible. Furthermore, "dragon" has the disapproving connotation especially in British English, referring to a woman who behaves in an aggressive and frightening manner (ODE). Concerning "malfoy", "mal" is a prefix to provoke something bad in English, and "foy" means "faith" in French. There are sufficient examples containing the prefix "mal" to convey the meaning of "bad" such as "malnutrition-a poor condition of health", "maltreat-to be very cruel to a person or an animal", "malpractice-careless behavior while in a professional job", "malfunctionthe failure of a machine to work correctly", "malodorous-having an unpleasant smell". On the one hand the strategy of preservation serves to perpetuate the exoticism of the original, but on the other hand it can be tough for the general recipients in Vietnam to explore the semantic implications conveyed through this meaningful name.

\footnotetext{
${ }^{3}$ Retrieved 24 January, 2018 from https://www. behindthename.com/name/ronald
}

\subsection{Proper names of Hogwarts professors}

HPPS is situated in the context of a magical boarding school; hence, not only students but also professors play a crucial role in developing the theme of the narrative. The title "Professor" is employed at the beginning of each name of the teachers, and it is literally translated into Vietnamese as "Giáo sư".

Similarly, the strategy of preservation was adopted for the names of the professors, which poses both pros and cons for the translated text. An instance is "Albus Dumbledore", the headmaster at Hogwarts school. "Albus" is firmly rooted in Latin bearing the meaning of "white", which vividly describes his distinctive appearance with the noticeable long white beard. In the story, Rowling (2014, p.6) describes the character in details: "He was tall, thin and very old, judging by the silver of his hair and beard". For Dumbledore, this word means "bumblebee in Old English... seemed to suit the headmaster, because one of his passions is music and I imagined him walking around humming to himself ${ }^{(4)}$ ", Rowling (1997). By the same token, the non-translation of "Albus Dumbledore" preserves the far-flung fragrance of this name and creates the uniqueness of the wizarding world in the translated text, but it would be demanding for the Vietnamese audience to perceive the semantic meaning that fits the character appearance through his name.

It also poses the target readers tough challenges in interpreting the name "Minerva McGonagall" when being preserved in the target culture. Minerva is imbued with a mythological Latin name for Athena who is a cerebral Roman goddess of wisdom. According to the description in the story, Minerva McGonagall is perfectly a "strict and clever" professor (Rowling, 2014, p.101).

\footnotetext{
${ }^{4}$ Retrieved 22 January 2018 from http://www.accioquote.org/articles/list1999.html
} 
The Scottish surname McGonagall can be traced back to the Celtic name "Conegall", implying the "bravest". It can be seen that this name evokes both Roman and Celtic mythic traditions and contributes to expressing the striking personality of the character Minerva McGonagall.

Another case is the name of Professor "Severus Snape". This name is alliterative to fill the story with the beauty of the poetic language. Thus, the non-translation in the target culture preserves the alliteration, contributing to the aesthetic beauty of the target literary text. Nonetheless, Severus is indicative of Latin that means "severe", which is true to the vivid account of this character in the story "Snape had the gift of keeping a class silent without effort" (Rowling, 2014, p.109) and "Snape liked hardly any of the students" (Rowling, 2014, p.112). For a British reader, the surname "Snape" might provoke negative connotation. It derives from

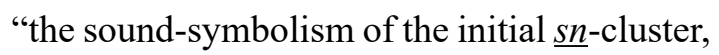
which features in words such as $\underline{\underline{n}} \mathrm{eer}, \underline{\underline{n}} \mathbf{i d e}$, snoop, sneak, snap or even snake" (Davis 2003, p. 79), which is closely associated with the "Snake" symbol of Slytherin House where this character is the head teacher. Since this name serves the function of reflecting the personality of characters, the target book lovers might find it arduous to notice the sound symbolic meaning through non-translation.

In the same way, Quirrell in the name of Professor Quirrel appears as always "nervous" (Rowling, 2014, p.54, p.55, p.101) and squirrelly all over the story. There is sufficient evidence reflected through his utterances such as "P-P-Potter, stammered Professor Quirrel [...] c-can't t-tell you how p-pleased I am to meet you". As this name performs the function of developing the personality of the character, the author believes that the strategy of preservation possibly poses a comprehension-related problem to the target readers in interpreting the semantic meaning of the name.

The Vietnamese rendition might also partially lose the information about the character Professor Sprout through her name "Sprout". The name "Professor Sprout" firmly links to the subject of Herbology that she teaches at the wizard school. "Three times a week they went out to the greenhouses behind the castle to study Herbology, with a dumpy little witch called Professor Sprout, where they learned how to take care of all the strange plants and fungi” (Rowling, 2014, p. 106). Semantically, a sprout is a part of a plant that begins to grow (ODE). It can be seen that this name effectively aids the audience in recalling the clear role of the character among an abundance of character names in the story.

\subsection{Proper names of Hogwarts founders}

The Hogwarts school is comprised of four Houses and established by four founders, namely Godric Gryffindor, Helga Hufflepuff, Rowena Ravenclaw, and Salazar Slytherin. All of these names are alliterative to create the artistic beauty of the literary text, and the strategy of preservation was adopted to deal with them. Hence, the Vietnamese audience can enjoy a sense of rhythm and distinctly remembers all of these names.

Nonetheless, the names of Hogwarts founders perform the function of imparting information about each House. For instance, "Gryffindor" is the combination of "gryffin" and "d'or". "Gryffin" alludes to a creature with the body of a lion and the wings and head of an eagle (ODE), and "d'or" literally means golden in French, which is the symbol of the Gryffindor House. Regarding "Ravenclaw", "raven" makes reference to a large bird of the crow family with shiny black feathers, and "claw" literally means one of the sharp curved nails on the end of a bird's foot (ODE). The image of a bird is seen as the symbol of the Ravenclaw House. Likewise, Slytherin 
becomes a pun "slithering" that means sliding as an action of a snake. In the story, a snake is adopted as the symbol of the Slytherin House.

To put it in a nutshell, the names of Hogwarts founders provide vivid description associated with each House. In this sense, the author assumes that it can be challenging for the target readership to access these intentional implications via non-translation.

\subsection{Proper names of other characters}

The implications are evident in not only student and professor names but also an abundance of characters in the wizarding environment. Similarly, the proper names of other characters were preserved in the Vietnamese text.

The antagonist of Harry Potter is Voldemort. "Voldemort" is comprised of "volde" and "mort", which reveals considerable details about this character. In French, the word "mort" means "death", and the combination of "voldemort" means the flight from the death. Throughout the whole story, "Voldemort" desires to resurrect from his own death and brings the tragic death to the entire magical world. The employment of French in creating this name takes the audience back to the tradition of Normans French as the language of government in England. Historically, the Norman conquered England in 1066, replacing the native English nobility with Anglo-Normans and introducing Normans French as the ruling language in England (Algeo, 2010). By borrowing a French name, the author clearly highlights the ruling power of the Dark Lord along with his aspiration to dominate the wizard community. Hence, the overall name "Voldemort" vividly evokes his will to fly from the death, his corpse, and his yearning for murder. For that reason, it would be intricate for the general target readers to grasp the purposeful messages through the preservation of "Voldemort".

"Sirius Black" is a case that cultivates the sense of myth and displays the traits of the character. "Sirius" is well known as the brightest star visible from any part of the Earth. It is also noted as the "Dog Star", which is honored in the ancient Egyptians. In ancient Egypt, the name Sirius is associated with the Egyptian gods Osiris, Sopdet and other gods. It is common to see numerous Egyptian temples designed with the architecture with the light of Sirius reaching the inner chambers. In the story, Harry sees a giant black dog hanging around him, and it is then disclosed that Sirius Black is that giant black dog. There comes an obvious clue that Sirius is able to transform himself into a black dog. It can be seen that Rowling successfully constructs the magical theme of the story and depicts the peculiarities of the character through this mythological name. The target recipients might find it hard to explore the implicit meaning of this name via the strategy of preservation.

It is also true for the case of Harry's mother "Lily"; this name is deeply rooted in Latin of "lilium". In the prehistoric Greek, white lily belonged to Hera, an ancient Greek goddess who represents the ideal woman. In Christian symbolism, the lily is associated with the Virgin Mary ${ }^{(5)}$, and this kind of flower makes a reference to purity and innocence. These properties fit the description of the character Lily as an outstanding girl at school in the story. By contrast, the implication of intense irritation is provoked from the name "Petunia ${ }^{(6) "}$. In the story, Petunia possesses a "shrill voice" (Rowling, 2014, p.13) and "nearly twice the usual amount of neck, which came very useful as she spent so much of her time craning over garden fences, spying on the neighbors" (Rowling, 2014, p.1).

For Harry's cousin, Dudley Dursley has

\footnotetext{
5 Retrieved 24 January, 2018 from http://www. traditioninaction.org/religious/f034 EasterLily.htm

6 Retrieved 24 January, 2018 from http://www. flowermeaning.com/petunia/
} 
a name carrying the unappealing connotation because it reminds the readers that he is a dud. This name is alliterative, aiding to the memory of both the source and the target readers. At home, Dudley is commonly called as "Dinky Duddydums" or "Icke Dudleykins" by his mom. In these cases, the translator adopts literal translation for the descriptive part and non-translation for the proper name. Dinky Duddydums" and "Icke Dudleykins" are rendered into "Dudley cục cưng” and "bé Dudley-đờ-tí-tẹo" respectively. The descriptive translation creates the same humorous effect as the source text and expresses the affectionate emotion of Dudley's mom in using these nicknames.

Messages embedded in proper names are scattered all over the story. The names of authors who wrote magical books closely connect with the contents of the books. For instance, Phyllida Spore is the author of the book entitled "One Thousand Magical Herbs and Fungi". "Spore" is one of the tiny cells that are produced by some plants and develop into new plants. Newt Scamander is the author of "Fantastic Beasts and Where to Find them", and Newt refers to a small animal with short legs, a long tail and cold blood living both in water and on land. Arsenius Jigger wrote the book "Magical Drafts and Potions", and Arsenic refers to a chemical element, an extremely poisonous white powder. Evidently, there exists a strong bond between the author names and the contents of the books. Therefore, the author believes that the general target readers might not notice such linkage when these names are preserved in the translated text. Adopting a similar standpoint, Juzelènienè, Petronienè, Kopylov (2016, p.1) also remind that "all languages have particular personal names, some of which are deeply rooted in the culture of the speakers of the specific language; consequently, they can pose unique difficulties in the comprehension of culture-specific texts. It is interesting to note that some personal names have various allusions indicating sex, age, geographical belonging, history, specific meaning, playfulness of language and cultural connotations when omitting this implied information results in unacceptable translation".

\subsection{Proper names of ghosts}

Rowling creates ghost names to paint a vivid picture about an ancient Hogwarts castle as a haunted place in Britain. "Peeves" is a mischievous ghost at the Hogwarts community, and the name of this ghost is preserved in the target text. According to ODE, "peeve" literally means a cause of annoyance. "Peeve" is evident in the idiom "somebody's pet peeve" that means something a person intensely dislikes. In the story, this ghost is mischievous, and it causes constant irritation among students and teachers at Hogwarts school. Apparently, the semantic meaning of this name accurately reflects the striking personality of this ghost.

There are proper names of ghosts that contain an epithet in HPPS. Ephithet is an adjective or phrase that is employed to describe the characteristics of somebody, especially in order to give praise or criticism. For these names, literal translation was adopted for the descriptive part, and the proper name was preserved. The instances are "Nearly Headless Nick", "Efric the Eager", "Emeric the Evil" and their Vietnamese equivalents of "Nick Suýt Mất Đầu", "Efric Háo Hức" and "Emeric Quỷ sứ" respectively. By the combination of non-translation plus literal translation, the translator expresses her artistic creativity that makes the Vietnamese translation peppered with the eccentric humor. For instance, the equivalent "Suýt Mất Đầu" vividly depicts the ghost Nearly Headless Nick who was beheaded, and his head is still attached to the neck with a thin line connected 
with his neck by a piece of skin. "Háo Hức" and "Quỷ sứ" successfully provoke the sense of humor, and the audience can recognize the traits of these mischievous ghosts through their translated names. The name "Bloody Baron" and its Vietnamese equivalent "Nam tước đẫm máu" also accurately describe the personality this ghost who is covered in blood during his life when he kills himself.

To put it simply, the proper names in HPPS can be categorized into three primary groups. The first group is the conventional names that perform the function of mere identification. In these cases, the translated text beautifully preserves the exoticism in the target culture. The second group is the loaded names that perform the multiple functions of providing not only identification but also description on the traits of the characters. On the one hand, the strategy of preservation effectively conserves the foreignness in the target text. On the other hand, it possibly challenges the general Vietnamese readers in decoding the implications embedded in these purposeful names. It is justifiable that literary proper names pose tough challenges for the translator; however, there would be partially functional loss in Vietnamese translation through mere preservation. Therefore, the following section 4.6 is devoted to discuss on the possible recommendations to deal in these meaningful literary proper names. The third group is the names containing an ephithet. In these cases, the descriptive part is functionally translated into Vietnamese, and the proper name is preserved in the target text. In these cases, the translator successfully expresses creativity and imagination in her rendition that makes the Vietnamese translation peppered with the eccentric humor.

The summary about the roles of literary proper names attached with relevant examples in HPPS is demonstrated in the Table 1. Functions of literary proper names in HPPS as follows:

\begin{tabular}{|c|c|c|}
\hline \multicolumn{2}{|c|}{ Functions of literary proper names in HPPS } & Examples of literary proper names in HPPS \\
\hline \multirow{5}{*}{$\begin{array}{l}\text { Offer information } \\
\text { about the } \\
\text { characters }\end{array}$} & - Provoke connotation & $\begin{array}{l}\text { Harry, Hermione, Ron, Draco Malfoy, Voldemort, } \\
\text { Snape }\end{array}$ \\
\hline & $\begin{array}{l}\text {-Specify the role of the } \\
\text { character }\end{array}$ & Ron \\
\hline & $\begin{array}{l}\text {-Provide the description of the } \\
\text { physical traits }\end{array}$ & Albus Dumbledore \\
\hline & $\begin{array}{l}\text {-Provide the description of the } \\
\text { personal traits }\end{array}$ & $\begin{array}{c}\text { Professor Albus Dumbledore, Professor Mineva } \\
\text { McGonagall, Professor Severus Snape, Professor } \\
\text { Quirrel, Lily, Petunia }\end{array}$ \\
\hline & $\begin{array}{l}\text {-Offer information related to the } \\
\text { character }\end{array}$ & Professor Sprout, Sirius Black \\
\hline $\begin{array}{l}\text { Entertain the } \\
\text { readers, } \\
\text { Aid the readers } \\
\text { in remembering } \\
\text { numerous names }\end{array}$ & & $\begin{array}{l}\text { Mineva McGonagall, Severus Snape, Godric } \\
\text { Gryffindor, Helga Hufflepuff, Rowena } \\
\text { Ravenclaw, Salazar Slytherin, Nearly Headless } \\
\text { Nick, Bloody Baron }\end{array}$ \\
\hline Create humor & & Nearly Headless Nick \\
\hline $\begin{array}{l}\text { Create aesthetic } \\
\text { appeal }\end{array}$ & & $\begin{array}{l}\text { Mineva McGonagall, Severus Snape, Godric } \\
\text { Gryffindor, Helga Hufflepuff, Rowena } \\
\text { Ravenclaw, Salazar Slytherin, Nearly Headless } \\
\text { Nick, Bloody Baron, Fat Friar }\end{array}$ \\
\hline
\end{tabular}


4.6. Recommendations for the strategies in translating proper names in a literary text

As discussed above, the strategy of preservation was adopted for the rendition of most of the names. The names of characters in HPPS are derived from Latin, French, Greek, and old English to create the milieu of a magical school in an imaginary world, and they carry the multilayered meanings. The findings of the present paper reveal that the names in Harry Potter book pose the translator huge challenges because they are constructed with an inherent Britishness that taps into specific historical naming practices in English literature (Brondsted and Dollerup, 2010; Compagnone and Danesi, 2012). However, the author believes that if no effort were made for the rendition of proper names, there would be partially functional loss. The author agrees with Bantas (2010, p.82) that "if we are pledged to give reader of translations what the author intended for the readers of the original, translators have to find-even huntthese intentions, discern them, make sure we have fully grasped or understood them and strive to render them".

To compensate for the possible loss, the following translation strategies have been proposed. Early in the vast body of literature, Vinay and Darbelnet (1958) offer the translation technique of explicitation. It means that the translator adds implicit information in the source text to the translation. The addition can be in the form of the text gloss, footnotes, chapter-end notes, end-of-volume glossary, or separate volume glossary. Newmark (1988) continues to recommend footnotes as a translation procedure to deal with culture-specific concepts such as proper names. Though different in wording, Coille and Verschueren (2006), Cui (2013) arrive at the similar solutions, including calque, translator's note, borrowing and paraphrase, non-translation plus additional explanation.
More recently, Manini (2014) argues that interpreting and selecting an interpretation are obviously essential elements of any exercise in translation, but it can also a risky business for the translators in general; therefore, "if explanatory footnotes serve the translators' purpose, they can be inserted with relative ease into a work of narrative fiction to inform the reader about what had to be left out" (Manini, 2014, p. 173). Additionally, Manini (2014, p. 173) suggests that "the use of explanatory notes-or other forms of meta-textual comment such as the translator's preface, etc. can perfectly well be envisaged to compensate for the semantic loss that occurs when loaded names are not translated". In accordance with previous authors (Vinay and Darbelnet, 1958; Newmark, 1988; Coille and Verschueren, 2006; Cui, 2013; Manini, 2014), the author of the present paper suggests that adopting non-translation plus additional explanation could be considered for literary proper names in HPPS, so that the target readers can fully grasp the intentional ideas conveyed through literary meaningful names.

\section{Concluding remarks}

As a challenging issue, the strategy of preservation was adopted for the rendition of most of the literary meaningful names in HPPS. While the strategy of preservation advantageously remains the foreignness of the original to the target text, there would be partially functional loss via the mere preservation. To make up for the semantic loss, the strategy of addition is proposed. Through the strategy of addition, the translator could still adopt preservation to conserve the exoticism in the target culture, but supplement the text with necessary information (Davis, 2003). The additional information could be in the form of end-of-volume glossary or separate volume glossary, which facilitates the accessibility of the target audience towards the purposeful implications in literary meaningful names. 


\section{References}

\section{Vietnamese}

Nguyễn Văn Trào (2014). Nghĩa biểu trưng văn hoá của các từ chỉ động vật trong tiếng Anh và tiếng Việt. Tạp chí Khoa học Xã hội Việt Nam, 77(4), 93-103.

\section{English}

Aixela, J. F. (1996). Culture-specific items in Translation. In R. Alvarez, \& C. A. Vidal (Eds.). Translation, Power, Subversion, 52-78. Frankfurt: Multilingual matters.

Algeo, J. (2010). The Origins and Development of English Language. Cengage Learning Academic Resource Center: Michael Rosenberg.

Bantas, A. (1994). Names, Nicknames, and Titles in Translation. Perspectives: Studies in Translatology, 2(1), 79-87.

Brondsted, K. \& Dollerup, C. (2010). The names in Harry Potter. Perspectives: Studies in Translatology, 12(1), 56-72.

Coillie, V. J. \& Verschueren, W.P. (2006). Children's Literature in Translation. Manchester: St. Jerome Publication.

Compagnone, V. \& Danesi, M. (2012). Mythic and Occultist Naming Strategies in Harry Potter. Names. A Journal of Onomastics. 60(3), 127-134.

Cui, J. (2012). Untranslatability and the Method of Compensation. Theory and Practice in Language Studies, 2(4), 826-830.

Davis, E.E. (2003). A Goblin or A Dirty Nose? The Translator: Studies in Intercultural Communication, 9(1), 65-100.

Fernandes, L. (2006). Translation of Names in Children's Fantasy Literature: Bringing the Young Reader into Play. New Voices in Translation Studies, 2, 44-57.

Hermans, T. (1988). 'On Translating Proper Names, with reference to De Witte and Max Havelaar', in Michael Wintle (ed) Modern Dutch Studies. Essays in Honour of Peter King, London \& Atlantic Highlands NJ: Athlone Press, 11-24.

Inggs, J. (2003). From Harry to Garri: Strategies for the Transfer of Culture and Ideology in Russian Translations of Two English Fantasy Stories. Meta, 48(1-2), 285-297.

Juzelėnienè S., Petronienė S., Kopylova K. (2016). The Translation of Proper Names from English to Lithuanian in "Steve Jobs" by W. Isaacson. Proceedings of International Conference on Teaching and Learning English as an Additional Language, GlobELT. Turkey, April, 2016, 800-805.

Klingberg, G. (1986). Children's Fiction in the Hands of the Translator. Malmo: Liber/ Gleerup.

Manini, L. (2014). Meaningful Literary Names. The Translator, 2(2), 161-178.
Newmark, P. (1988). A Textbook of Translation. New York: Prentice Hall International.

Nilsen, A.P. \& Nilsen, D.L.F. (2005). Six literary functions of name-play in J.K. Rowling's Harry Potter books. Onoma: Journal of the international council of onomastic sciences, 40, 65-81.

Nilsen, A.P. \& Nilsen, D.L.F. (2009). Naming Tropes and Schemes in J.K. Rowling's Harry Potter Books. The English Journal, 98(6), 60-68.

Oittinen, R. (2008). From Thumbelina to Winne-thePooh: Pictures, Words and Sounds in Translation. Meta: Journal des traducteurs, 53(1), 76-89.

Rowling, J. K. (1997, 2014). Harry Potter and the Philosopher's Stone. London: Bloomsbury.

Stevenson, A. (2015). Oxford Dictionary of English. Oxford: Oxford Dictionary Press.

Vinay and Darbelnet, (1958). Comparative Stylistics of French and English: A Methodology for Translation. Amsterdam and Philadelphia, PA: John Benjamins.

Wellek, R. \& Austin, W. (1976). Theory of Literature. Harmondsworth: Penguine.

Wyler, L. (2003). Harry Potter for Children. Meta: Translators' Journal, 48, 5-14.

\section{Websites}

Office for National Statistics-Baby NamesEngland and Wales. (2011). Retrieved $15^{\text {th }}$ February, 2018 from https://www.ons. gov.uk/peoplepopulationandcommunity/ birthsdeathsandmarriages/livebirths/datasets babynamesenglandandwalesbabynamesstatisticsgirls

Behind the name. (2018). Retrieved 24 $4^{\text {th }}$ January, 2018 from https://www.behindthename.com/name/ronald

Horvat, M, T. (2016). The Lily: Symbol of the Annunciation \& the Resurrection. Retrieved $24^{\text {th }}$ January, 2018 from http://www.traditioninaction. org/religious/f034_EasterLily.htm

Monarchs of Britain. (2013). Retrieved 25 $5^{\text {th }}$ January, 2018 from http://www.britannia.com/history/ h6.html

Petunia Flowers. Its meaning and symbolism. (2018). Retrieved 24 $4^{\text {th }}$ January, 2018 from http://www. flowermeaning.com/petunia/

What happened in 1999? (2007). Retrieved $22^{\text {nd }}$ January 2018 from http://www.accio-quote.org/articles/ list1999.html 


\title{
DİCH TÊN RIÊNG TRONG VĂN HỌC: \\ TRƯỜNG HỘP DỊCH TÊN RIÊNG TRONG TẬP TRUYỆN HARRY POTTER SANG TIẾNG VIẸT
}

\author{
Triệu Thu Hằng \\ Khoa Su phạm tiếng Anh, Trường Đại học Ngoại ngũ, ĐHQGHN, \\ Phạm Văn Đồng, Cầu Giấy, Hà Nội, Việt Nam
}

Tóm tắt: Dịch tên riêng trong văn học là một trong những vấn đề đầy thách thức nhưng rất thú vị của chuyên ngành Dịch thuật. Chính vì vậy, bài báo này đã tiến hành phân tích các chiến lược dịch tên riêng trong văn học, cụ thể là nguyên tác "Harry Potter and the Philosopher's Stone" (2014) sang bản dịch tiếng Việt "Harry Potter và Hòn đá phù thuỷ” (2016) thông qua phương pháp mô tả và so sánh dựa trên khung phân tích các chiến lược dịch của Davis (2003). Kết quả nghiên cứu cho thấy dịch giả đã áp dụng chiến lược chuyển nguyên ngữ (không dịch) đối với hầu hết các tên riêng trong tác phẩm này. Từ đó, chúng tôi đưa ra các gợi ý và đề xuất đối với dịch tên riêng trong văn học từ Anh sang Việt.

Tù̀ khoá: dịch tên riêng, văn học 